\title{
Wśród oracji komicznych XVII wieku
}

Maria Barłowska 


\section{Maria Barłowska}

\section{Wśród oracji komicznych XVII wieku}

$\mathrm{M}$ ówcy staropolscy od dawna znani są jako wdzięczny temat satyry. Wystarczy przywołać w pamięci często komentowane obrazki obyczajowe z satyr braci Opalińskich, fraszek Wacława Potockiego czy barwne sceny z udziałem oratorów utrwalone w anegdotach. Jednak - szczególnie wobec nadal pokutującego stereotypowego spojrzenia na dawne oratorstwo jako dziedzinę słowa jeśli nawet nie mało wartościową, to przede wszystkim przygnębiająco w swej obfitości nudną — pokazanie kilku przykladów wkraczania mówców siedemnastego wieku w obszar komizmu może okazać się drobnym rysem różnicującym owo mało wyraziste tło.

Już w 1967 r., przedstawiając staropolskie kazania humorystyczne, Kazimiera Żukowska formulowała zachętę „do badań nad dziedziną piśmiennictwa dotąd u nas niemal nieodkrytą i niekomentowaną"1. Kreśląc genezę i tło rozwoju humorystycznych przemów kościelnych, autorka poszukiwała również śladów istnienia innych komicznych oracji. Niestety, najczęściej musiała ograniczać się do snucia przypuszczeń i stosowania trybu warunkowego. W sferze owych możliwych obszarów występowania w kulturze dawnej Polski komicznych mów sytuowała Rzeczypospolitą Babińską i obyczajowość odpustową, traktując istnienie parodystycznych odmian różnych gatunków retorycznych jako konieczność:

„Mowa”, „oracja”, „kazanie” — w kraju o rozwiniętym systemie parlamentarnym i wyjątkowo obserwowanych konwencjach w sposobie bycia w życiu oficjalnym i indywidualnym: towarzyskim i rodzinnym, wymagającym

\footnotetext{
${ }^{1}$ K. Żukowska, Próba spojrzenia na staropolskie kazania humorystyczne, „Odrodzenie i Reformacja w Polsce" R. 27: 1982, s. 193.
} 
"gotowości" występowania z wypowiedzią o cechach retorycznie sformalizowanych - musiały mieć swój parodystyczny rewers dosyć wcześnie².

Jednak bezpośredni dowód ich istnienia, oprócz jedynie wzmiankowanej mowy pogrzebowej w dziele Jakuba Boczyłowica Orator politicus albo wymowny polityk... (Toruń 1699, s. 517)³, badaczka znalazła w Opisie obyczajów ... Kitowicza. Jest to świadectwo funkcjonowania „śmiesznych oracji” w obchodach Niedzieli Palmowej, kiedy wierszowane przemowy „o poście, o śledziu, o kołaczach wielkanocnych, o nuży szkolnej i inne tym podobne" wygłaszały najpierw dzieci, a po nich dorośli przebierańcy przemawiali zgodnie ze swoją rolą. Ale jest to równieź świadectwo nieuniknionego odchodzenia tego obyczaju czasów saskich w przeszłość. Nim jednak do tego doszło, jak pisze autorka: „Formy parodii oratorskich kwitły zapewne we wszystkich środowiskach zwartych, o wykształconym, zrytualizowanym obyczaju, określonym statusie społecznym i profilu kulturalnym"4.

Dziś można stwierdzić, że intuicje badawcze Żukowskiej okazały się słuszne, bowiem zostało już odnalezionych i scharakteryzowanych kilka przykładów humorystycznych oracji weselnych. Można więc poprzestać na ich przeglądowym zarysowaniu i tylko dorzucić nowe szczegóły ${ }^{5}$.

Że „same wesele szczególnym nazywamy weselem”, wielokrotnie przekonywali staropolscy oratorzy ${ }^{6}$, a obyczajowość epoki pozostawiła liczne tego przekonania świadectwa. Całkiem więc naturalnie wśród wielu rodzajów „wesołości” związanych $\mathrm{z}$ tą ściśle określoną w obyczajowości epoki ceremonią wydają się mieścić komiczne mowy. Jednak zbiór potraktowany jako weselne mowy komiczne mieści w sobie co najmniej dwie kategorie zabytków. Pierwszą z nich tworzą przemowy, które przypisane są konkretnym mówcom, mają znanych z imienia i nazwiska bohaterów. Są przypisane, a więc nie ma pewności, czy rzeczywiście zostały przez nich wygłoszone albo co naj-

2 Ibidem, s. 194.

3 Zukowska twierdziła także: „kilka tekstów kazań i innych oracji humorystycznych zawiera sylwa sygnowana inicjałami Wespazjana Kochowskiego, twórcy następnej po Babinie w dziejach polskiego humoru rzeczypospolitej - Rzeczypospolitej Waśniowskiej..." (ibidem, s. 210), jednak dokładny przegląd zawartości rękopisu Biblioteki Czartoryskich 1274 I potwierdza zapisanie w nim tylko dwóch kazań; jakichkolwiek oracji w rękopisie brak.

${ }^{4}$ Ibidem, s. 200-201.

${ }^{5}$ Zob. M. Barłowska, Oddawanie panny z przygana: frantowskie i nie tylko, w: Sarmackie theatrum III. Studia historycznoliterackie, red. R. Ocieczek, M. Walińska, Katowice 2006, s. 97-118; M. Trębska, Staropolskie szlacheckie oracje weselne. Genologia - obrz̨̨d - źródła, rozprawa doktorska obroniona na Wydziale Polonistyki Uniwersytetu Warszawskiego w 2007 r.; prac. dokt. BUW nr 899, s. 369-372, 377-379. Uprzejmie dziękuję Autorce za udostępnienie mi tekstu dysertacji.

${ }^{6}$ Zob. A. S. Radziwill, Mowa Księcia Jegomości Pana Kanclerza W[ielkiego] Ks[ięstwa] Lit [ewskiego] oddając Jej M[ó́́] Pannę Chorażankę Koronną przy szlubie, rkps Archiwum Głównego Akt Dawnych w Warszawie, Archiwum Radziwiłłów II, ks. 15, s. 284. 
mniej napisane. Pierwszy tego rodzaju zabytek to oddawanie panny Buczackiej panu Gulskiemu przez Mikołaja Mieleckiego. Zarówno osoba mówcy — znanego z ciętego języka wojewody podolskiego, jak i bohaterów: Katarzyny z Buczackich i Stanisława Gulskiego są autentyczne. A samą możliwość wygłoszenia mowy na weselu zapewne jeszcze przed 1578 rokiem uprawdopodabniają ulotne pisma $z$ lat bezkrólewia, dokumentujące podejrzaną karierę Gulskich i przywołujące skandal obyczajowy, jaki miał się zdarzyć na dworze Jana Buczackiego z udziałem „pacholęco” służącego mu Stanisława Gulskiego. Znacząca nierówność mówcy i bohatera, satyryczny, ganiący ton, czytelne, ale nie drastyczne w dosłowności aluzje do „znajomości” młodych, w połączeniu $\mathrm{z}$ atmosferą renesansowego dworu magnackiego możliwości takiej przynajmniej nie wykluczają. Drugi przykład tego rodzaju, opisany przez Małgorzatę Trębską, pochodzi jednak już z czasów Jana III Sobieskiego. Jest to często notowana w rękopisach pod nazwiskiem biskupa chełmińskiego Kazimierza Opalińskiego mowa z podziękowaniem od Franciszka Gałeckiego za Rozalię Dzieduszycką. I w tym przypadku bohater oracji znany jest $z$ licznych utworów polityczno-okolicznościowych z czasów elekcji 1697 roku, karykaturujących go, zgodnie $z$ nazwiskiem, jako bardzo jurnego mężczyznę. Jednak ten „rubaszny i dosadny” tekst wydaje się nie do pomyślenia w ramach autentycznej akcji oratorskiej: w ustach biskupa i w obecności pary królewskiej?

Jednoznaczne, osobowe nakierowanie obydwu przemów pozwala je czytać w perspektywie paszkwilu, jednak dla badacza staropolskiego oratorstwa znacznie ciekawsze wydaje się to, co stanowi podstawowe źródło ich komizmu — gra z konwencją i parodia, aż do zaprzeczenia zasad tworzenia poważnych oracji: oddawania panny i dziękowania za nią. Sygnałem wpisania się obydwu mów w te właśnie wzorce są — poza określeniami tytułowymi - formuły właściwego oddawania i dziękowania, pojawiające się na końcu, a odnoszące się bezpośrednio do ceremonii ${ }^{8}$. Zamiast jednak zwracającej się ku przyszłości, istotnej symbolicznej treści: przekazania przez opiekunów władzy rodzicielskiej mężowi i przyjęcia "godnego towarzysza" do nowej wspólnoty rodowej, uaktywniają one niemieszczące się w panegirycznym kontekście aspekty wydarzeń. U Mieleckiego pojawia się, obniżające styl przez swą lakoniczność i dosłowność, określenie „rzeczy”:

A iż im ślub dano, ego non obsum. Niechajże z sobą mieszkają, ponieważ się dobrze przedtym znają.

U Opalińskiego natomiast — zaskakująca w erotycznej wymowie interpretacja herbowej alegorii:

${ }^{7}$ Zob. M. Trębska, Staropolskie szlacheckie oracje weselne..., op. cit., s. 370.

8 Terminy „oddawanie właściwe” i „dziękowanie właściwe” stosuję w znaczeniu nadanym im przez Małgorzatę Trębską (zob. Staropolskie szlacheckie oracje weselne..., op. cit., s. 217). 
upewnia, że serdecznym afektem wrodzonej lubości wzbudzony, pasąc lumina wdzięcznym urody' prospektem, im się żarliwiej zapatruje, tym chciwiej do należytego kwapiąc pastwiska, rodowity baran in signum ugłaskanej skoczy owieczki9.

Wspólnym środkiem budowania satyrycznego wizerunku bohaterów jest też w obydwu tekstach przekształcenie rodowej pochwały, stanowiącej we wzorcowych realizacjach podstawowy materiał inwencyjny przemów. Oratorzy mówią o tym, o czym mówić powinni, ale tak, by inne rozłożenie akcentów, zderzenie schematu z nietypową treścią, zaskakujące sfunkcjonalizowanie znanych motywów stworzyło karykaturalne tego wzorca wykrzywienie. Tak na przyklad Mielecki rozwija „przyziemny” motyw bogactwa i antywzorzec szlacheckiego etosu, uderzając w podejrzaną karierę rodziny Gulskich, a Opaliński parodiuje legendę herbową i panegiryczne etymologizacje nazwiska i rodowej siedziby Gałeckich. Dopiero jednak subtelne sygnały językowe, zapożyczanie $z$ oficjalnej konwencji szczególnie popularnych zwrotów (na przykład „tak się podobało temu...”; „człowiek równej fortuny”; „ojczystej fortuny zostawa posesorem”) i najbanalniejszych, najczęściej przywoływanych refleksji (jak: „Za czasem wszytko się mieni") tworzą żywą tkankę tych oratorskich parodii.

Jednocześnie to ten aspekt łączy „historyczne” teksty z mowami o charakterze jawnego oratorskiego żartu, wpisującymi się w szerokie obszary frantowskiego humoru. Komiczną kwalifikację tekstów zdradzają już same formuły tytułowe. Odnalezione dotąd zostały mowy określane jako: Oddawanie panny dworskie, frantowskie raczej panu mtodemu; Oddawanie panny trefne, alias baculus in angulo; Serbska przy oddawaniu panny mtodej oracyja; Oddawanie Pani Elżbiety $P[a n u]$ Marianowi $i^{10}$ i Oracyja polityczna tego wieku frantów Anno Domini $1644^{11}$. Wszystkie one należą również do najbardziej reprezentacyjnego zespołu mów weselnych, ale nie wszystkie w jednakowym stopniu do oficjalnego wzorca oddawania panny się odnoszą. W całkowicie niskich rejestrach humoru sytuują się dwie pierwsze mowy. Wykorzystują one przede wszystkim środki komizmu słownego. W Oddawaniu panny trefnym... bierze się on z "zanurzenia” w żywiole biesiadnym. Mówca walczy o prawo do głosu, powtarza się, przerywa i upomina audytorium, co realizowane jest $z$ zastosowaniem inwektyw i naśladujących język pijacki przekształceń fonetycznych. Z kolei w Oddawaniu panny dworskim... pojawia się naśladowanie jąkania się, które służy przede wszystkim podkreśleniu podtekstów erotycznych. Nawet jednak w parodystycznym przekształceniu jest ta mowa znacznie bliższa poważnym oracjom przy oddawaniu panny. Najsilniejszy jednak związek ze wzorcem łączy pozostałe trzy oracje — przy czym dwie z nich: Oddawanie Pani Elżbiety... i Oracyja polityczna... posługują się wyda-

${ }^{9}$ Cyt. za: M. Trębska, Staropolskie szlacheckie oracje weselne ..., op. cit., s. 369-370.

${ }_{10}$ Zob. M. Barłowska, Oddawanie panny z przygana..., op. cit., s. 103-111.

${ }^{11}$ Zob. M. Trębska, Staropolskie szlacheckie oracje weselne..., op. cit., s. 378-379. 
rzeniowym konkretem. W pierwszym przypadku jest to wprowadzenie imion głównych bohaterów, a nawet powołanie się na koligacje rodzinne, w drugim równie konkretne, chronologiczne i topograficzne osadzenie przedstawianych wydarzeń. Fikcjonalności pierwszego zabiegu dowodzi posłużenie się w komponowaniu mowy kontaminacją dwu wzorców: oddawania panny Buczackiej i silnie nasyconej poprzez aluzje erotyką Serbskiej... oracyi. Ale i w drugim przypadku we wprowadzeniu do biografii bohatera autentycznych nazw miejscowości (Jarosław, kopylski jarmark) można podejrzewać nie tyle zatarty adres paszkwilu ${ }^{12}$, co dobrze znany mechanizmom anegdoty zabieg wzmacniający prawdopodobieństwo zdarzeń przez ich osadzenie w realiach ${ }^{13}$. We wszystkich trzech mowach dla zrealizowania komizmu konieczne jest jednak istnienie i rozpoznane przez odbiorcę "poważnego" wzorca przemowy przy oddawaniu panny. Tylko ono gwarantuje zderzenie podobieństwa i niepodobieństwa, które staje się podstawowym sposobem działania tych żartów oratorskich. Odbiorca powinien znać reguly rządzące konstrukcją poddanej biograficznemu porządkowi laudacji bohatera, by w pełni odczuć nieprzystawalność do akceptowanego modelu złodziejskich „nauk”, jakie pobierał bohater Oracyi politycznej..., by docenić pozorowaną we wprowadzaniu banalnych przysłów moralistykę, czy rzekomą rodową pochwałę w Serbskiej... oracyi, by czerpać przyjemność nie tylko z odkrycia niedwuznacznych erotycznych aluzji, ale także z subtelnej literackiej gry z oficjalną konwencją. Służąc prawdopodobnie uprzyjemnianiu życia towarzyskiego, komiczne mowy weselne musiały spełniać podstawowy warunek zaistnienia parodii aktualność, rozumianą jako świadomość używanych środków stylistycznych, chwytów, zasad kompozycji, w istocie świadomość cech retorycznego gatunku ${ }^{14}$.

Wszystkie opisywane dotąd mowy należały do najczęściej notowanych w rękopisach i powielanych w druku weselnych oracji oddawania i dziękowania za pannę. Komiczne realizacje innych odmian oracji weselnych, na przykład oddawania prezentu, znane były co najwyżej jako temat fraszek (jak Wespazjana Kochowskiego Serbska oracyja). Okazuje się jednak, że w jednym z rękopisów zapisano Oddawanie ucieszne upominku od miasta Krakowa księżnej Wiśniowieckiej, matżonce JMP Koniecpolskiego, przez JMP Wojciecha Bystrzonowskiego [?] ${ }^{15}$. Ścisłe określenie okoliczności każe wierzyć, że jest to zapis autentycznej oracji. Jej tekst jest bardzo krótki:

\section{Miasto Kraków kłania się W[aszej] Ks[iążęcej] M[ości] M[iłościwej] Pannie, a przysyła przeze mnie upominek należyty, srebro to, dobre to, czternastej próby to, nie moje to, Waszej Ks[iążęcej] M[oś]ci należy to.}

${ }_{12}$ Taką sugestię sformułowała Małgorzata Trębska w pracy Staropolskie szlacheckie oracje weselne..., op. cit., s. 379 , przyp. 1076.

${ }^{13}$ Por. np. częste ukonkretnianie zdarzeń we fraszkach Wacława Potockiego.

${ }^{14}$ Zob. K. Żukowska, op. cit., s. 206-207.

15 Rękopis Biblioteki Polskiej Akademii Umiejętności i Polskiej Akademii Nauk w Krakowie, sygn. BPAU-PAN Kr 1046, k. $65 v$. 
Jest to nie tyle żart oratorski, co raczej świadectwo wystapienia niefortunnego mówcy, związane najprawdopodobniej z odbywającym się w 1667 roku weselem Stanisława Koniecpolskiego z Eugenią Katarzyną Wiśniowiecką ${ }^{16}$. Zapisane na prawach satyrycznej anegdoty, zostało opatrzone równie lakonicznym opisem akcji: „I ukłonił się." W takim więc rozumieniu stanowi świadectwo nie komizmu, lecz wpisanej w rzeczywistość śmieszności ${ }^{17}$. Jednak utrwalenie oddawania w postaci zapisu przenosi zabytek w obszar tekstów, a więc stawia kolejnego odbiorcę już wobec komicznej sytuacji komunikacyjnej. Modelem, do którego się ona odnosi i którego rozpoznanie przez odbiorcę zakłada, jest mowa przy oddawaniu upominków.

Choć ofiarowywanie prezentów następowało w różnych momentach konkurów i zalotów, i różne, również obrzędowo i symbolicznie uwarunkowane były prezenty, to krótkie wystąpienie wpisuje się w sytuację oddawania po ślubie. Odbywało się ono zwykle w kolejnych dniach wesela, gdy - szczególnie podczas uroczystości w magnackich domach - wiele godzin zabierało reżyserowane zasadami pokrewności, „starszeństwa i urzędu" uroczyste przekazywanie podarków. Czynili to najczęściej nie sami ofiarodawcy, lecz reprezentujący ich orator, a otrzymywali podziękowanie przez osobę pełniącą rolę mówcy ze strony panny. Podobnie jak w innych mowach ceremonialnych, naczelne zasady rządzące przemową wynikały z ogólniejszych zasad grzeczności. Co prawda, mowy tego rodzaju byly stosunkowo krótkie, ale krótkość i związana z nią dosłowność stanowi w „mowie uciesznej” wyraźne naruszenie konwencji. Chociaż mówca zrealizował na początku podstawowy nakaz wskazania ofiarodawcy i określenia jego pełnych szacunku uczuć wobec adresatki (służy temu skromny w swej prostocie gest „kłaniania się"), odwołał się też do swojej roli (znów bardzo prosto), ale już przedstawienie samego prezentu musiało zaskoczyć. Weselny orator powinien był bowiem opisać podarek, ale nie wolno mu było mówić o jego materialnej wartości. Materia mogła stać się jedynie źródłem dla konceptycznych pomysłów, które miały pomniejszyć znaczenie prezentu, a powiększyć wymiar duchowy czynności jego ofiarowania. Ona sama również winna poprzez zabiegi amplifikacji, często oparte na metaforyzacji, zyskać na powadze. Kończące mowę właściwe ofiarowanie było także poddawane szczególnie silnemu działaniu grzecznościowych formul. Komiczna nieprzystawalność widoczna jest więc nie tylko w wyeksponowaniu niemal „handlowej” wartości srebra, ale też w bezceremonialnym pominięciu woli adresatki co do przyjęcia upominku. Równie nieodpowiednie — na tle zwykle kunsztownego rozwijania toposów z definicji — jest ogólnikowo natrętne, zaimkowe wskazywanie przedmiotu. Przy czym efekt komiczny nasila łamiące zasady prozodii i okresowego układu wyrazów finalne umieszczenie zaimka. W ten sposób zamiast

${ }^{16}$ Zob. W. Dworzaczek, Genealogia, Warszawa 1959, tabl. 138.

17 Zob. J. Ziomek, Spójność teorii i teoria spójności, w: idem, Powinowactwa literatury. Studia i szkice, Warszawa 1980 , s. 327. 
będącego naruszeniem zasad stylu, ale umotywowanego uporządkowania figuralnego, pojawia się ilustracja nieporadności językowej, pochodzącej z żywiołu potoczności. Ostatecznie więc przykład ten dobrze wpisuje się w znany mechanizm komicznej degradacji, zapewniający odbiorcy przyjemne poczucie wyższości.

Inaczej niż w przypadku mów weselnych, samo istnienie komicznej mowy pogrzebowej może wydać się zaskakujące ${ }^{18}$. A jednak już określenie: Przedmowa żatobna miana od jednego żotnierza na pogrzebie drugiego, także żotnierza, zmartego, który z Morgonic jadąc do Piątniczan, podpiwszy sobie, utoną $w$ rzece nazwanej Zbrocza budzi niepokój. Co prawda w prywatnych zapisach oracji można znaleźć przykłady utrwalania szczegółowych i niecodziennych okoliczności wydarzeń, ale szczerość tak daleko idąca wydaje się niezwykla $^{19}$. I rzeczywiście, mimo ścisłej lokalizacji tragicznych zdarzeń (i nazwy miejscowości, i rzeki są autentyczne), pozwalającej rozpoznać jako scenerię teren dawnego powiatu kamienieckiego ${ }^{20}$, cała przemowa ma prześmiewczy i fikcyjny charakter. Jej przynależność gatunkową pozwala ściślej określić zakończenie:

Aleć już przypatrzywszy się monomachijej Park tych złośliwych z tym kawalerem, ta przytomność WMPP jako encyklopedyją żalów, tak i dokończeniem niech będzie, które aby ww żarłocznego Tryfoniusza otworzyste kawerny wpadszy, karawanem naładowanym pomyślnych pociech i fortun w domu tym zacnym potężnie wsparte i nagrodzone zostały, WMPP pozostalym prz[yjacio]1[o]m życzymy. A my tymczasem $p[e r]$ colophone na powszedni biszkokt i jagody wdowicze mirrą metamorfozowane pokłuszemy ${ }^{21}$.

Jest to mowa wypowiadana w imieniu gości, a więc jej podstawowym celem powinno być pocieszenie pozostałych krewnych. I słowa pocieszenia się tu znalazły. Odpowiednio uroczyście brzmi peryfrastyczne określenie śmierci: „monomachija Park złośliwych z tym kawalerem", nie zaskakuje również epitetowa inwektywa użyta w nim wobec greckich bogiń, gdyż podobne „wyrzekania” na zly ich charakter towarzyszą całej poezji i prozie żałobnej XVII wieku. Z kolei peryfrastyczne, uwznioślające określenia uczest-

${ }^{18}$ Długą tradycję mają za to komiczne nagrobki.

${ }^{19} \mathrm{~Np}$. w autografie Stanisława Sarbiewskiego, rkps Biblioteki Czartoryskich w Krakowie sygn. BCz 376 IV, s. 517.

${ }^{20}$ Piątniczany — wieś nad Zbruczem, należąca w XVII w. do Lanckorońskich (zob. Stownik geograficzny Królestwa Polskiego i innych krajóu stowiańskich, red. B. Chlebowski, W. Walewski, F. Sulimierski, t. 8, Warszawa 1887, s. 60-61); Morgonice - prawdopodobnie Morgowice, po białorusku Morgówicy - wieś nad rzeką Możanką, prawym dopływem Berezyny, w powiecie borysowskim (zob. ibidem, t. 6, s. 678).

${ }^{21}$ Rkps BCz 1657 IV, s. 146, uzupełnienia według rękopisów: Biblioteki Kórnickiej PAN, sygn. BK 975 oraz BPAU-PAN Kr 1046. O popularności mowy świadczy jej przedrukowanie w Wymownym polityku... Jakuba Boczylowica z 1699 r. (s. 117 Oracyja pogrzebowa: „Mokrawe w pozorze, bystrolotne w uporze..."), jednak w postaci skażonej i z objaśnieniami leksykograficznymi świadczącymi o niezrozumieniu tekstu. 
ników pogrzebu wydają się bardzo „wyszukane”, ale łatwo byłoby wskazać podobne im, uniezwyklające wypowiedź pomysły. W oratorskim dialogu miejsce takiej przemowy przypada po wygłaszanej $w$ imieniu rodziny (i symbolicznie samego zmarłego) mowie $\mathrm{z}$ zapraszaniem na żałobny chleb. Formuła zapraszania wraz z podziękowaniem za udział w uroczystości pojawia się zawsze na końcu oracji. W mowie ,jednego żołnierza” jej odpowiednikiem jest deklaracja podążenia na „powszedni biszkokt” i ,jagody wdowicze”. Formulicznie stosowane wyrażenie ,żałosny chleb" było nieraz w mowach pogrzebowych zastępowane przez bardziej urozmaicone i wyszukane stylistycznie odpowiedniki, jak np. „panem doloris z nim jeść raczyli” (BCz 373 IV, s. 513); „żałosnego chleba dziś zażyć IchM dopomogli” (BCz 1881 s. 115); „opłakanym chlebem JM gardzić nie raczyli” (ibidem, s. 120), ale zawsze stanowiło zaproszenie do współudziału w smutku. Kiedy jednak zamiast chleba pojawia się „biszkokt” — modne ciasto, od razu rodzi się skojarzenie nie ze stypą, ale z radosną biesiadą. Drugie wymienione przez dowcipnego mówcę „danie” tylko pozornie przynależy do kulinariów. Została tu bowiem wykorzystana homonimiczna dwuznaczność ,jagód”. Odpowiednim „towarzystwem” w biesiadnych przyjemnościach dla biszkoptu okazuje się sama wdowa. Aluzja do możliwych przyjemności, jakie czekają u wdowy, to tylko ostatni akcent satyrycznego tematu.

Został on wprowadzony w części refleksyjnej. Łączy ona dwa obwarowane antyczną jeszcze tradycją tematy żałobne: pochwałę i opłakiwanie. Jednak laudacja odnosi się nie tyle do zmarłego, co do jego rodu, ściślej: obecnych jego przedstawicieli, a najściślej - pani małżonki. Materia jednak samej pochwały jest dość dziwna:

Bystrookie w dozorze, nieużyte w uporze Parki, wziąwszy spronę [?] z Morgonic na dychtowanej gonduli, przyflotowawszy, wypleniły Heliotropion prześwietnego dziardynu domostwa Ich $\mathrm{M}$ [ościów] $\mathrm{P}$ [anów] $\mathrm{N}$ M[iłościwych] P[anów], na których niemal wszytkich dziulki i fiksuzy, brandepury i szaperany z głogowskiego szarłatu, w pozostałej zwłaszcza małżeństwa lidze, kochanej bidzie, a podsobnego rumelijasza pod konopno-jamurłukowym dygdykiem widzę. O niezbita tyranko, Klotos! o żarłoczna Atropos! o wartka i nienasycona prządko Lachesis! Na coście kawalerowi temu w bystrej Zbroczy, ‘gdy on ochotnie w nię skoczy», tak niespodzianie zawarly mu oczy, skąd ta dama banderelle stambolskiej roboty we łzach serdecznych ustawnie moczy. Skąd i ja, lubo na schyłku pokrewności, jako gorzkich drożdży pokłócony na sercu liquor wylewać muszę. Jakoż niepodobna, żeby i sami murzowie, bojarowie, bejowie i burkułabowie pogańscy tak zacnego kawalera litując straty w Muzoraj$\mathrm{kach}^{22}$ serc swoich uczuć nie mieli hypokondryjacznej treści.

22 Być może od müsalấha — tureckie: ‘pokój, spokój'. 
Efekt komicznej nieprzystawalności rodzi już sam brak konsekwencji obrazowo-metaforycznej. Całkowicie ziemsko i swojsko — zgodnie z powszechną w baroku praktyką aktualizacji motywów mitologicznych ${ }^{23}$ - potraktowane Parki, poruszając się na podziurawionej gondoli, wyrywają z rodowego ogrodu słonecznik - najwspanialszy zapewne jego kwiat - znowu zgodnie z popularną metaforyką żałobną ${ }^{24}$. Dalej jednak, gdy mówca zamienia opowieść alegoryczną na perspektywę obserwatora, a w konsekwencji można by się spodziewać wyrażanej wprost, ewentualnie kondensowanej w synekdochach pochwały rodu ${ }^{25}$, pojawia się niezrozumiałe wyliczenie materii i ubiorów. Choć trudno tu, przy przekształceniach fonetycznych nazw obcych różnie poświadczonych w przekazach, jak i możliwym stosowaniu żartobliwych neologizmów, o jednoznaczną identyfikację, chodzi prawdopodobnie o elementy stroju (dziuła — kaptur, sarpanka — zapinka lub suknia, teperelle — krezy), różne rodzaje sukni (fiszment, brandenbura) i materiałów (jarmułuk, dyftyk, szarłat) ${ }^{26}$. Komiczne nagromadzenia tego rodzaju słownictwa mają swą długą tradycję w staropolskich tekstach satyrycznych, w Reja Krótkiej rozprawie... rozpoczętą, a kontynuowaną w XVII wieku - jak choćby w roku 1678 w Jakuba Łącznowolskiego Nowym zwierciadle modzie dzisiejszego stroju akomodowanym, damom polskim, które się modnie nosza, gdzie nazywane są one nawet „szatną litaniją” i „szat rejestrowaniem”. Zamiast więc opiewania cnót widoczne są znaki bogactwa i materializmu, odniesione najbardziej bezpośrednio

${ }_{23}$ Zob. np. M. Walińska, Mitologia w staropolskich cyklach sielankourch, Katowice 2003, s. 66-71.

${ }^{24}$ Zob. M. Włodarski, Barokowa poezja epicedialna. Analizy, Kraków 1993, s. 78-82.

25 Typowa realizacja np. w mowie Jerzego Ossolińskiego na pogrzebie Stanisława Cikowskiego: „Tu świetne infuly, tu bulawy nieprzyjaciołom straszne, tu stołki wysokie” (rkps Biblioteki Narodowej w Warszawie, sygn. BN BOZ 823, k. 205).

${ }^{26}$ Dziuła - w XV w. kaptur lub kapuza sukienna albo filcowa, noszona jako ochrona przed deszczem (I. Turnau, Stownik ubiorów. Tkaniny, wyroby pozatkackie, skóry, broń i klejnoty oraz baruy znane w Polsce od średniowiecza do poczatku XIX u'., Warszawa 1999, s. 50; dalsze lokalizacje - ibidem); fixment (fiszment) - okrycie kobiece noszone w 2 poł. XVII w. (s. 56); brandenbura (brandebura, brandenburla, prandypura) [fr. brandebourg] — suknia zimowa lub okrycie damskie zdobione pasmanteria, noszone w XVII i XVIII w. „Brandebourgs” to rzędy pasmanteryjnych pętlic modnych w tym czasie we Francji, w mundurach husarskich i ubiorze cywilnym. Nazwa ozdoby przeniosła się na strój (s. 28); serpanka (sarpanka) [z per-tur. serpenek - hełm, misiurka, siatka, łac. serpens, ros. serpjanka] - 1. w XV-XVI w. chustka na głowę; 2. w XVI w. część chłopskiej odzieży; 3. w XVI-XVIII w. kobieca suknia; 4. zapinka do łączenia części odzieży (s. 163); szkarłat (szarłat) [średniow. łac. scarlatum] — 1. tkanina lub ubiór o ciemnoczerwonej barwie uzyskanej w wyniku farbowania kermesem lub koszenilą (s. 177); kałmuk [fr. calmuque] - kosmata tkanina bawełniana, niekiedy wzorzysta, przywożona z Azji w XVII-XVIII w. lub jarmuluk [tur. jaghmuluk] — podwójny barchan importowany ze Wschodu, co najmniej od pol. XVII w. (s. 78); tyftyk (dyftyk, dywtyk) [tur. tiftik] — cienka, bardzo miękka, wzorzysta tkanina z wełny angorowej lub wełniana o jedwabnej osnowie, tkana splotem skośnym lub płóciennym i broszowana. Wyrabiana na Wschodzie, używana w Polsce w XVI-XVIII w. (s. 193); teperelle (trpele, trepelle, trepelele, treperelle, trzeperelle) [starowłos. trapello - choragiewka] - krezy lub inne wykończenia wykroju szyi i rękawów noszone w modzie wł. i hiszp. w XVI w. (s. 187); rumeliasz — prawdopodobnie nazwa tkaniny pochodzącej z Rumelii. 
do „małżeństwa ligi, kochanej bidy”. Za całąjej charakterystykę wystarczy naszkicowana tylko scena gwałtownego płaczu, w której znowu istotną rolę gra szczegól - mokre od lez bogate kryzy przy rękawach sukni. Trudno nie zestawić tego satyrycznego ujęcia z najsłynniejszym i chyba najostrzejszym w wyrazie obrazem wdowiego żalu z satyry Krzysztofa Opalińskiego Na pogrzeby i zbytki w nich:

[...] Gdy się tedy ruszą konie $z$ trunną,

Pocznie ryczeć — nie płakać — złośna białogłowa,

Lament jakiś fałszywy zmyślając i słowa.

O mdlość oraz nie trudno, zwłaszcza gdy kto widzi,

Bo jako z męża swego, tak i z inszych szydzi.

Cebula w chustce pędzi gwałtem wyciśnione

Łzy z oczu, w ten czas, gdy im każą, wypuszczone.

Za ciałem idąc ryczy, woła: „O mój drogi

Mężu!" - Lecz już w sercu drugi. $[\ldots]^{27}$

W takim zestawieniu, amplifikująca opłakiwanie gradacja, choć sięga do ulubionego przez pogrzebowych mówców i poetów schematu geograficznej hiperboli, jeszcze mocniej ujawnia swoje prześmiewcze nacechowanie. Efekt komiczny wzmacniają też zabiegi stylistyczne, pozorujące dbałość o kunsztowność i wysoki rejestr stylistyczny wypowiedzi, jak wyrównanie (apostrofy do Parek) i rymowanie członów („Zbroczy / oczy”; ,roboty / moczy”) oraz nagromadzenia niezwykłych, obco brzmiących wyrazów (nawet z aliteracją: „bojarowie, bejowie, burkułabowie”). Ostatecznie jednak komiczna mowa pogrzebowa wpisuje się w popularny obyczajowy nurt satyry białogłowskiej. Potwierdza to również swoisty komentarz w popularnej postaci aforystycznego czworaka ${ }^{28}$ zapisany pod tekstem mowy w przekazie z rękopisu BCz 1657 IV, s. 146. W dziesięciu paralelnych wersach przedstawia on poprzez przypisanie im odpowiednich atrybutów pochlebną charakterystyką panien, mężatek i wdów, przeciwstawiając te kobiece „stany” wyśmiewanym „babom”, np.: „Pannom miód, wino mężatkom, małmazyja wdowom a pomyje babom". Jednocześnie komiczna oracja pogrzebowa przynależy do grupy krasomówczych parodii, które w sposób karykaturalny przetwarzają sposoby wyrażania łatwo rozpoznawalne w ramach żałobnej konwencji.

Ostatni przykład komicznej mowy nie jest w historii literatury novum. Wotum kasztelana Mieleszki jako „ciekawą mowę [...] z rękopismu Józefa hr. Sierakowskiego” opu-

\footnotetext{
${ }_{27}$ Cyt. za: K. Opaliński, Satyry, opr. L. Eustachiewicz, Wrocław 1953 (BN I 147), s. 38-39 (satyra 6 ks. I, w. 65-72).

${ }^{28}$ Por. np. ostatnie prace na ten temat: R. Grześkowiak, Czterech autorów „Czwartaka”: czworak filologicz$n \gamma$, w: idem, Barokowy tekst i jego twórcy. Studia o edycji i atrybucji poezji „wieku rękopisów”, Gdańsk 2003, s. 129-134; J. Ziembiński, Trzy końskie wiersze z epoki baroku: od hipologicznej fraszki do lirycznej pamiątki, w: Sarmackie theatrum..., op. cit., s. 48-56.
} 
blikował w drugim tomie swego Zbioru pamiętników o dawnej Polszcze... Julian Ursyn Niemcewicz ${ }^{29}$.Zyskało ono popularność, o czym świadczą kolejne jego polskie wydania: $\mathrm{w}$ historii literatury Michała Wiszniewskiego jako zabytku oratorstwa z XVI w. ${ }^{30}$, przedrukowanie fragmentów przez Hannę Malewską w Listach staropolskich z epoki Wazów ${ }^{31}$ a niedawno przypomnienie przez Janusza Tazbira jako apokryfu z epoki ${ }^{32}$. Żywe zainteresowanie mowa Mieleszki budziła u historyków ukraińskich, białoruskich i rosyjskich. Ukoronowaniem badań nad tekstem stało się jego krytyczne wydanie przez Bohdana Struminsky'ego ${ }^{33}$. Autor do pięciu dotąd znanych przekazów oracjiji ${ }^{34}$ dodal sześć kolejnych $^{35}$, zestawił ich synopsę i zaproponował stemmę, na podstawie której zrekonstruował tekst zabytku, publikując go na koniec w transkrypcji na język ukraiński.

Zarówno w druku, jak i w przekazach rękopiśmiennych mowa występuje z dokładnym określeniem okoliczności: Mowa JW JP Iwana Mieleszki, kasztelana smoleń[skiego] na sejmie $w$ Warszawie za króla Zygmunta miana $1589^{36}$. Data zdaje się jednoznacznie wskazywać na osobę Iwana Daniłowicza Mieleszki, marszałka smoleńskiego, o którym wspomina nawet Tadeusz Wasilewski, autor biogramu jego syna, Jana Eliasza: „wsławionego mową wygłoszoną rzekomo przez niego na sejmie 1589 r." ${ }^{\text {". Tytuło- }}$

29 Zob. J. U. Niemcewicz, Pamiętniki o dawnej Polszcze..., t. 2, Warszawa 1822, s. 477-479.

${ }^{30}$ Zob. M. Wiszniewski, Historia literatury polskiej, t. 8, Kraków 1851, s. 480-484 (jest to edycja na podstawie rękopisu z biblioteki Joachima Chreptowicza).

31 Zob. H. Malewska, Listy staropolskie z epoki Wazów, Warszawa 1977, s. 237-240 (na podstawie druku Niemcewicza).

32 Zob. J. Tazbir, Żale pana Mieleszki, w: idem, Falsyfikaty historyczno-literackie, Poznań 2002, s. 58-60 (jest to przedruk z wydania Niemcewicza).

${ }^{33}$ Zob. Pseudo-Meleško, A Ukrainian Apocryphal Parliamentary Speech of 1615-1618, ed. B. A. Struminsky, Cambridge, Massachusetts 1984. Tutaj również stan badań, zob. s. 9-11; za nim referuję dalej obcojęzyczną literaturę przedmiotu.

${ }^{34}$ Są to według oznaczeń Struminsky'ego przekazy: S - druk spolonizowanego tekstu: J. U. Niemcewicz, op. cit., s. 341-344; B — druk z cyrylickiej kopii, która jednak pochodziła z zapisu polskim alfabetem: W. Łastowski, Histonjja biełaruskaj (kryŭskaj) knihi, Kowno 1926, s. 446-449; $\mathrm{W}_{1}$ - polski druk M. Wiszniewskiego, op. cit., s. 480-484; K — opublikowany cyrylicą z licznymi zmianami, ale pochodzący z polskiego przekazu w cerkiewnym rękopisie w Vestnik Jugo-Zapadnoj $i$ Zapadnoj Rossii, 1, Kijów 1862, cz. 1, s. 91-97; KK - tekst drukowany cyrylicą, bez wskazania źródła, ale ze śladami polskiego zapisu: Akty, otnosjašciesja k istorii Južnoj i Zapadnoj Rossii, t. 2, St. Peterburg 1865, nr 158, s. 188-190.

${ }_{35} \mathrm{D}$ - rkps BN 6608, kopia polska z 1 pol. XVIII w.; Cz — rkps BCz 1662, s. 458-461, kopia polska; St — rkps BUW TNW 29/2-47, s. 971-973, kopia polska z XVIII w.; O - rkps BOss 249, s. 76-78, kopia polska z XVIII w.; P — rkps BCz 966 s. 457-458, kopia polska z XVIII w.; W chiwum M. Wiszniewskiego, rkps BJ 949, fasc. 238, k. 12-13, prawdopodobnie druga kopia rękopisu z biblioteki Chreptowicza, który stał się podstawą druku; $M$ - tylko wspomniany przez Własta Łastowskiego rękopis polski z XVIII w.

${ }^{36}$ Ponieważ opublikowany przez Struminsky'ego tekst jest transkrybowany na język ukraiński, na potrzeby niniejszego artykułu zdecydowałam się cytować za rękopisem (BN 6608 II, k. 112-113v.), nie podejmując w tym miejscu dyskusji z przedstawioną przez autora hipotezą stemmy.

37 T. Wasilewski, Mieleszko (Meleszko) Jan Eliasz h. Korczak, hasło w: Polski słownik biograficzny, t. 20, Wroclaw 1975, s. 769. 
we określenie „kasztelana smoleńskiego” w konfrontacji z wymienioną przez mówcę małżonką: „panią mścisławską” to ślad późniejszego powstania jeśli nie samego tekstu, to jego zapisu (znane kopie pochodzą z XVIII w.) - mowa odnosi się do osoby kasztelana mścisławskiego. Jednak zdanie, w którym kasztelan tłumaczy się, że nie przebywa przy królu, bo nie ma królewszczyzny, wiarygodność tytułowej daty podważa:

kazat prawdy $i$ staruju Urszulu Korolowu Jej Mitosty milenko $w$ ruczku pocatowat, kak druhije motodszyje senatorczyki, ne dywite sie Mostywy Panowie i Bratia, wik wikom ukazywajet siwizna $w$ borode, a czort $w$ ladwiach $z a$ pojasom bo na choroszoje widenie stawku kusit...

Wspomniana tu ukochana przez królową „stara Urszula” to na pewno Urszula Meierin, opiekunka dzieci Zygmunta III Wazy ${ }^{38}$. Przybyła ona do Polski wraz z jego pierwszą małżonką, Anną Habsburżanką dopiero w roku 1592 jako jej dwórka, a pozostała na królewskim dworze aż do śmierci w roku $1635^{39}$. Jej wpływy były powszechnie znane, czego wymownym świadectwem jest przekazany przez Albrychta Stanisława Radziwiłła opis śmierci króla Zygmunta III, któremu do ostatnich chwil towarzyszyła Urszula Meierin, jak i zamieszczona trzy lata później jej pośmiertna laudacja ${ }^{40}$. Zdobycie pozycji na dworze niewątpliwie jednak wymagało czasu, trzeba by więc dołożyć do daty jej przyjazdu co najmniej kilka lat ${ }^{41}$, a w takim razie niemożliwe by było przypisanie oracji zmarłemu około roku 1600 Iwanowi Daniłowiczowi Mieleszce. Również dlatego, że brak innych potwierdzeń, by piastował on wspomniane godności. Na pewno w 1589 roku kasztelanem mścisławskim był Szymon Matwiejewicz Wojna ${ }^{42}$, a kasztelanem smoleńskim Stanisław Pawłowicz Naruszewicz (nominowany 30 maja 1588, zmarły z początkiem 1589 roku), a po nim Ostafi Wasylewicz Tyszkiewicz (10 kwietnia

\footnotetext{
${ }^{38}$ Niepewne wydaje mi się twierdzenie Struminsky'ego: „he offends Sigismund III by calling his stewardess of the houshold, Ursula Meierin, "Her Majesty the Queen" (phr. 128) in allusion to gossip about the King's affair with Ursula” (op. cit., s. 103). Fragment można odczytać inaczej: „starą Urszulę, Królowej Jej Miłości miłą, w rączkę pocałowal" (podobnie tekst rozumiał Niemcewicz).

${ }^{39}$ Zob. H. Wisner, Wtadystaw IV Waza, Wrocław 1995, s. 8.

${ }^{40}$ Zob. A. S. Radziwiłt, Pamiętnik o dziejach w Polsce, tł. i opr. A. Przyboś, R. Żelewski, t. 1, s. 109-112, $444-445$.

${ }^{41}$ Na pewno ujęcie jej roli w wotum współgra z opinią wyrażoną w Skrypcie o słuszności zjazdu stężyckiego: „Niech na nas włożą iugum bierniej ustawicznej, niech prawa, niech wolności odłogiem leżą, nie od rady, nie od senatu, ale od białej główki, od Urszulki jakiejś summa rerum dependeat, niech cudzoziemcy dominetur, a my peregrinemur w ojczyźnie naszej..." (Pisma polityczne z czasów rokoszu Zebrzydowskiego 1606-1608, t. 2: Proza, wyd. J. Czubek, Kraków 1918, s. 260). Janusz Tazbir stwierdza: „Na panoszenie się "panny Urszuli» zaczęto się skarżyć dopiero w latach rokoszu Zebrzydowskiego (1606-1608), co wskazuje, że rzekoma mowa Mieleszki nie mogła powstać wcześniej” (op. cit., s. 6, przyp. 13).

${ }^{42}$ Zob. J. Wolff, Senatorowie i dygnitarze Wielkiego Księstwa Litewskiego, Kraków 1885, s. 131.
} 
1689 , zmarły w $1590 \mathrm{roku})^{43}$. W dziejach obsady obydwu godności nie pojawiają się luki, które mogłyby sugerować istnienie jeszcze jednego, nieznanego historykom kasztelana. Pewne jest natomiast, że kasztelanię mścisławską otrzymał jeszcze jako prawosławny, już w 1606 roku, Jan Eliasz Mieleszko, późniejszy kasztelan brzesko-kujawski (1610) i smoleński (nominowany na początku 1615, zmarły 13 maja 1622 roku) ${ }^{44}$. Fakty te wskazują więc na postać Jana Eliasza Mieleszki, jako mówcy wskazanego w tytule, jednak niestety nie wyjaśniają obecności daty $1589^{45}$.

Sama mowa nawiązuje do oracji doradczej, którą senatorowie byli zobowiązani wygłaszać na początku sejmu w odpowiedzi na przedstawianą przez kanclerza propozycję królewską ${ }^{46}$. Wotum nie miało tak wyraźnie określonej konwencji jak sejmowe mowy ceremonialne, winno jednak odnosić się do królewskich postulatów, wpisywało się jednocześnie w przebieg obrad. Ta pojemność wotum, jako politycznej deklaracji programowej połączonej z możliwością swobodnego rozłożenia akcentów pomiędzy probacją i refutacją, znalazła również odzwierciedlenie w jego popularności w publicystyce ${ }^{47}$. Wypowiedź kasztelana mścisławskiego we wstępnych deklaracjach mieści się ogólnie w granicach egzordialnej topiki mów sejmowych. Należą do niej zarówno wyrazy troski o królewskie zdrowie ${ }^{48}$ jak i nacechowana skromnością prezentacja mówcy:

\section{Naijaśniejszy Mitostyuy Korolu i na mene Easkawyje Panowie Bratia! Wyjechaw- szy z domu Bohajesmosia pomoliw, szczoby $k$ wam zdorow pryjechaw, da $i$ Waszu Mitost zdorowo ohladat, da i prywitat. Pryszto mi z wami radity, a ja na hetych zjezdach nikoli nie bywat $i$ K Korolami Jego Mitosty nikoli nie zasedat...}

Jednak obwarowana konwencją niepewność mówcy okazuje się dalej jak najbardziej uzasadniona $\mathrm{w}$ zderzeniu nie $\mathrm{z}$ jego deklarowaną prostotą, lecz prawdziwym prostactwem. Podstawowym jego rysem jest wpisanie mówcy w schemat narodowościowe-

${ }^{43}$ Zob. Urzędnicy Wielkiego Księstu'a Litewskiego. Spisy, t. 4: Ziemia smoleńska i województwo smoleńskie XIV-XVIII $w$., red. A. Rachuba, opr. H. Lulewicz, A. Rachuba, P. P. Romaniuk, Warszawa 2003, s. 88. ${ }^{44}$ Zob. M. Liedke, Od prawostauia do katolicyzmu. Ruscy możni i szlachta Wielkiego Księstwa Litewskiego wobec uyznań reformacyjnych, Białystok 2004, s. 94.

${ }^{45}$ Struminsky nie znalazł śladów przemówień Jana Eliasza Mieleszki w diariuszach sejmowych z lat 1588-1615 - zob. Pseudo-Meleško..., op. cit., s. 150, przyp. 51.

${ }^{46}$ Struminsky zauważa, że sam mówca określa swe wystąpienie: „sentencyja”, co oznacza odmianę mowy parlamentarnej (nazwa stosowana wymiennie z „wotum” — dop. M. B.), jednak podkreśla, że jest to także wypowiedzenie opinii, a w tym wypadku protest, co potwierdza cytat: „but we have had an extraordinary talk about our various losses” (w rkps. 6608 III: „ale zradno pohoworyłysmo o roznych utratach naszych"). Generalny wniosek: „In other words, this is a literature of harsh truth, a politico-ethical satire unmusking the evil without beating around the bush" stanie się dalej przedmiotem polemiki po przedstawieniu odmiennego odczytania tekstu.

${ }^{47}$ Zob. E. Kotarski, Polska polityczna proza publicystyczna XVI i XVII wieku wobec tradycji retorycznej, w: Retoryka a literatura, red. B. Otwinowska, Wroclaw 1984, s. 64-65.

${ }^{48}$ Odnotowuje to Bohdan Struminsky, zob. Pseudo-Meleško..., op. cit., s. 152, przyp. 90. 
go stereotypu, a głównym mechanizmem jego uaktywnienia staje się język. Słusznie przypomina Struminsky, że już samo przemawianie przez senatora w obecności króla i na forum izby w języku innym niż polski (w określonych sytuacjach oczywiście także łaciński) byłoby odebrane jako przejaw nieznajomości obyczaju i wyraz grubiaństwa. Wymowna jest tu przytoczona przez autora opinia metropolity kijowskiego Piotra Mohiły (z 1644 r.), że byłoby niestosowne, gdyby on jako Rusin mówil do króla w senacie lub izbie poselskiej po grecku lub w języku cerkiewnym, za pośrednictwem tłumacza, gdyż byłby traktowany jako „obcokrajowiec lub głupiec”49.

Ilustracją prowincjonalności i braku orientacji w sprawach, o których przystało wiedzieć senatorowi Rzeczypospolitej, jest cała tematyka mowy. Przede wszystkim jej ukształtowanie dyspozycyjne ujawnia nieporadność mówcy. Zamiast wystapienia politycznego w uporządkowaniu wywiedzionym z propozycji, a odzwierciedlającym hierarchię ważności poszczególnych spraw, pojawia się konstrukcja swoiście addytywna, rządząca się swobodą stopniowo napływających, a z codziennego doświadczenia i bliskiego świata branych skojarzeń. Tak więc przede wszystkim Mieleszko staje się jednym z laudatoribus temporis acti. Najpierw wsparty narodowymi stereotypami przeciwstawia starą ruską prostotę serca chytrości Polaków i pazerności Niemców. Być może zastosowano tu w odniesieniu do Lachów komiczne odwrócenie utrwalonego w przysłowiach wyobrażenia charakteru narodowego, gdyż chytrość była w nich przypisywana właśnie Rusinom ${ }^{50}$. Od pochwały Zygmunta I, który „Niemcow kak sobak jakich nie chowat $i$ Lachow $z$ ich chy[tro]stiami wielmi nie lubit, ale Litwu i naszu Ruś lubitelnie miłowal" i krytyki Zygmunta Augusta mówca przechodzi niefrasobliwie do pochwały dawnej mody i wyrzekania na dzisiejszą:

$i$ horazd naszyje za jeho miewali się, chotiaj $w$ tak dorohich switoch nie chożywali, druhie bez nohawic kak bernardyny hulaty, a soroczki aż do kostek, a szapki a $\dot{z}$ do samoho pojasa nosili, daj Boże i teper, takoj hodyny $i$ stroju dozdaty [?]. Ja sam koli po domowomu tak $w$ domu uberu sie, to JM Pani mścistawskaja, matżonka moja nateszyty se i nasmotryty se na mene ne możet.

Literackie zacięcie wskazuje naszkicowana tylko scenka, wprowadzająca akcent familiarny i uzupełniająca tak prześmiewczą charakterystykę mówcy. Jeszcze udatniej komizmem sytuacyjnym, z wyraźnym zmysłem obserwacji, wyczuleniem na gest, ruch i dźwięk, posługuje się anonimowy autor, kreśląc obrazy niemieckiego małżeństwa i porucznika:

$i$ koli sam Nemczyn idet, albo żona jeho postupajet, i czerez skóru skrypit $i$ szelestyt, a dorohim piżmom waniajet; koliż do tebe porucznik pryjedet czestuj jeho

${ }^{49}$ Ibidem, s. 149, przyp. 50 .

${ }^{50}$ Zob. ibidem, s. 46. 
dostatkom, da jeszcze $i$ żonu swoju podle neho posady, a on sedit kak bies naduwszy sie, mirgajet, mrugajet, szapku albo kapelusz perekrywlajet $i z \dot{z}$ onoju poszeptywajet, stiskajet, da i $w$ doton skrobet.

W rysunku postaci został oczywiście wykorzystany dobrze znany satyrze obyczajowej typ bohatera, żołnierza-junaka. Pojawia się również postać przebiegłego i leniwego sługi:

I to Mitostywyje Panowie, nie małaja szkoda, stuhy chowaima Lachy, dawaj $\dot{z}$ jemu sukniu chwalendyszowoju, karmij jeho stasno, a z ich stuzby niczoho ne masz, tolko spodyń ukrawszy się na wysokich podkówkach do dewek dybe, da chodit, a z wielikoho kufla trubit, ty panie za stot, a stuha sobi za stot, ty za borszczyk a stuha Lach za bohatuju sztuku miasa, ty za flaszku, a on za druhuju, a koli btaho derżysz, tak on i z ruk wyderet, tolko pilnujet skoro by z dwora, a on mowczkom prytesajet se tobie i do żony.

Typy te dla wzmocnienia skojarzone zostają z narodowościowymi stereotypami, przy czym Polak zostaje wyraźnie połączony z nieobyczajnością ${ }^{51}$ :

I heta ne mataja zdajet się szkoda, koni nam dryhanty chowaty na stajni, dawajże jemu lito $i$ zimu owes $i$ seno, podstiłajże jeho, szczo nocz chowajże dla neho stuhu Lacha koniuszoho i masztalera, a z nich żadnej stużby nie pytaj, jesliż jeszcze Lach kak $\dot{z}$ erebiec bude rzat koto dewok kak dryhant koto kobyt, prijmiż dwóch Litwinow na straż $k$ nemu a bo $i$ sam ditko, mowiut, was ne upilnujet.

$\mathrm{Z}$ jednej strony więc poczucie krzywdy, ale z drugiej tym bardziej widoczny staje się nakaz nowej obyczajowości, konieczność aspirowania do zachodnich wzorców. W przekonaniu mówcy jednak wyższość dawnego potwierdza anegdota o kupowaniu zegarka: „I to na swite durnina, hodynniki mne prytrafito się na tandecie w Kijowie kupity..."; zegarek był drogi i szybko się zepsuł, więc „dobry to nasz hodynnik petuch szczo nechibne o pótnocy kukarekujet". Podobnie podstawową opozycję wspiera — kontynuująca tradycję równie starą jak satyra na stroje - krytyka nowych potraw, w której tortom przeciwstawione zostają dawne przysmaki, z wyraźną sugestią wpływu kuchni na postawę duchową:

dobra byta huska z hrybkami, kaczaczka $z$ perczykom, peczonka z cybuloju albo z czosnoczkom, a koli na perepyszny dostatok ryżowaja kasza z szafranem, wina

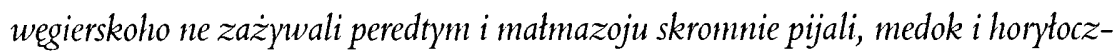

51 Potwierdzenie satyrycznego funkcjonowania motywu wskazuje Bohdan Struminsky, zob. Pseudo-Meleško..., op. cit., s. 159: „Kazalbym takowe dryganty, co około cudzych żon rżają, powałaszyć” (P. Wężyk-Widawski, Lekarstwo na uzdrowienie Rzeczypospolitej, Kraków 1603, nast. wyd. 1649). 
ku zobaty, ale hroszej po dostatku miewali, mury silnyje horody murowaty $i$ wojnu stawno, krepko, hutsczej jeszcze niż tepereczy doderżywali.

Dominującą w calej mowie satyrę obyczajową tylko uzupełniają elementy satyry społeczno-politycznej, jak na przykład narzekanie na złe rozdawnictwo królewszczyzn, na ruinę Podola i Wołynia czy na cudzoziemskich doradców. Chociaż poruszają one tematy społecznie ważne, to kontekst i sposób ich prezentacji odbierają im całą powagę.

Umysłowość samego mówcy dookreślają niskie, a nawet grubiańskie komentarze, jak na przykład: "takoho czorta po tycoju”; ,chodim kak poduretyje”; ,a kolib takoho bisa kutakom $w$ mordu" - zupełnie nie do pomyślenia w ustach senatora mówiącego do monarchy. Pojawiają się one stale w momentach szczególnego emocjonalnego poruszenia, jako komiczny dowód, przywoływanej na początku z weneracją, zasady mówienia: „po prostu prauym sercem howoryli, polityki nie znawali, a $w$ brod prawdoju jak złotoju $w$ oczy kidywali". Owa szczerość posunięta została aż do znieważenia przodków Zygmunta III przez stwierdzenie, że Zygmunt II August nie zasługiwał nawet na miano człowieka ${ }^{52}$.

$\mathrm{Na}$ tle dominującego w oracji odradzania, wskazywania coraz nowych „duractw”, jeszcze mocniej rysuje się występująca na końcu jedyna propozycja pozytywna, która wyrasta z krytycznej prezentacji damskiej mody:

ja by radyt, niech by biatoszyjki naszyje w zapinanyje dawnyje postroity się kazaki$n y$, a sznurowanyje na zadu nosity rozporki, a k tomu szczob z nemecka pludryny używaty, bytob warowniej i spokojniej, dobrochotniki mitosnyje ne tak by chutko lubitelniu skradywali bredniu.

Towarzysząca temu pomysłowi deklaracja mówcy: „Dalej o czym radyty, nie znaju...” jest jednocześnie prześmiewczym sygnałem końca, jak i mimowolnym gestem komicznej, obnażającej go szczerości. Zderzone z nią, z obszaru poważnego dyskursu politycznego wzięte przypomnienie o konieczności przebywania przy królu senatorów litewskich w roli doradców podkreśla całą nieprzystawalność materii i formy, sytuacji i niemożności jej sprostania, obowiązku i jego komicznej realizacji.

Literacki i satyryczny charakter wotum Mieleszki znalazł już wyraz w dotychczasowej literaturze przedmiotu, jednak zgoda co do ogólnej zasady nie oznacza wcale zgodności opinii co do interpretacji tekstu. Już w 1893 r. Josef Perwolf stwierdzil, że wotum nie mogło zostać wygłoszone w 1589 r. przez Iwana Mieleszkę i że jest to dzieło jakiegoś litewsko-ruskiego humorysty z XVII w. W 1907 r. Michajło Hruszewski, polemizując z Mikołą Sumcowem, uznał, że autor nie był przeciw nowym polskim zwyczajom, ale wyśmiewał w osobie Mieleszki konserwatywny typ piewcy dawnych czasów. Jako satyrę na wpływy obce odczytywał tekst Aleksander Brückner. Wreszcie satyryczny charak-

${ }^{52}$ Zob. Pseudo-Melesko..., op. cit., s. 103. 
ter wotum podkreśla Bohdan Struminsky, wskazując trzy możliwe jego rozumienia: krytyka poddania się Wielkiego Księstwa zachodnim wpływom, ośmieszenie tych, którzy przeciwko temu protestują lub parodia mowy parlamentarnej ${ }^{j 3}$. Autor przypomina, że poważne myśli zawarte w mowie, takie jak wspomnienie utraty Podlasia i Wołynia na rzecz Korony, przywilejów dla Niemców na Litwie, zajmowania urzędów przez obcokrajowców czy aluzja do utraty praw Litwy wobec Inflant, są zanurzone w całej masie zdań śmiesznych i niepoważnych.

This technique of mixing the serious and anserious, political satire and buffoonery misled Hruševs'kyj and Nud'ha. It seems that the seventeenth-century author of the $M[$ ieleško] $S[$ peech] was more complicated than his twentieth-century analysts who were not prepared to face a multidirectional, "capricious", wry work of art (in this sense a very modern one $)^{54}$.

I trzeba przyznać, że w argumentacji autora owo dążenie do komplikacji znaczeń eliminuje z pola widzenia najprostsze odpowiedzi.

Oto argumentem nie pozwalającym Struminsky'emu zaakceptować tezy o parodystycznym charakterze tekstu okazuje się język. Jego zdaniem, skoro parodia jest imitacją formy przy zmienionej treści, powinna była zostać napisana po polsku z wtrętami łacińskimi, zgodnie z językiem obowiązującym w senacie. A ponieważ polski był ogólnie znany wśród ludności ruskiej, ,there was no need to translate Polish words of literary personage into Ruthenian" (s. 106). Tłumaczenie takie w zaskakujący sposób wyklucza możliwość, by język mógł być nośnikiem satyryczności. A przecież satyryczne wykorzystanie języka ruskiego staje się zrozumiałe na tle postępującej polonizacji rodów litewskich i ruskich, w czasie której to, co im etnicznie właściwe, staje się stopniowo znamieniem peryferyjności i zacofania ${ }^{55}$. Jednak konsekwencje argumentacji badacza są jeszcze ważniejsze. Satyra napisana po polsku musiałaby być satyrą o innej treści, dla kogoś innego i w innym celu pisaną — po prostu zupełnie innym tekstem. Argument ten właściwie więc nie dotyczy analizowanego zabytku.

Zagadnieniem podstawowym w rozumieniu satyry jest odpowiedź na pytanie, kto i do kogo mówi. Struminsky cały rozdział poświęca określeniu autora tekstu, wykorzystując w tym celu dowody tekstowe i lingwistyczne. Wyłania się z rozbudowanej

53 Zob. ibidem, s. 105.

${ }^{54}$ Ibidem, s. 106.

55 Stylizacja językowa jako środek kształtowania karykatury odbierana jest jako zdeformowany język własny, a więc śmieszny — zob. A. Kępiński, Lach i Moskal. Z dziejów stereotypu, Warszawa 1990, s. 57. Ostatnio karykaturalne stylizacje na język gwarowy i przedrzeźnianie zniekształconego języka polskiego w ustach Niemca analizowała w tekstach sowizdrzalskich Teresa Banaś - zob. eadem, Pomiędzy tragicznością a groteskq. Studium z literatury i kultury polskiej schyłku renesansu i wstępnej fazy baroku, Katowice 2007, s. 215-221 (rozdz. Ambiwalencje znaczeń. O jezykowych eksperymentach sowizdrzałów). 
argumentacji bardzo dokładnie zarysowany wizerunek autora jako człowieka, którego językiem rodzimym był ruski (analiza cech dialektycznych prowadzi do określenia obszaru: między rzekami Horyniem i Styrem oraz między Pińskiem i Dubrowicą), który napisał cyrylicą tekst mowy, broni w mowie interesów mieszkańców Wielkiego Księstwa Litewskiego i wybrał jako porte-parole litewskiego senatora, zna pewne fakty z życia Mieleszki, a może nawet jego samego, ma jakąś wiedzę o litewskich prawach, jest szczególnie związany ze Smoleńskiem, a więc mógł być świadkiem zdobycia Smoleńska w 1611 r., a potem przeżywać frustracje związane z obsadzaniem przez króla nowych urzędów Polakami i spolonizowanymi mieszkańcami Wielkiego Księstwa Litewskiego, wreszcie mógł być urzędnikiem niższego szczebla, pewnie związanym ze sprawami wojskowymi. Nie miejsce tu na rozbudowaną dyskusję z poszczególnymi przesłankami i wyprowadzanymi z nich wnioskami, generalnie jednak niepokojące wydaje się zbyt łatwe, unieważniające literacki charakter tekstu, utożsamienie tego, co się mówi w satyrze i kto mówi w satyrze, z tym, co myśli jej autor. Jaskrawym przykładem jest snucie przypuszczeń na temat podeszłego wieku autora i jego zapewne młodej żony na podstawie satyrycznej wycieczki na temat kobiecych strojów. Zderzanie poszczególnych tematów podejmowanych w mowie ze światem realnym nie jest wystarczające, za każdym razem bowiem należy zakładać pośrednictwo literackiej fikcji, odczytywać je $\mathrm{w}$ ramach gatunku i jego konwencji.

Jeśliby nawet przyjąć argumenty autora, to jak pogodzić wynikające $\mathrm{z}$ nich dalsze pytania z jego określeniem tekstu: ,this is a literature of harsh truth, a politico-ethical satire unmasking the evil without beating around the bush" (s. 106). Pytanie podstawowe dotyczy funkcjonalności wyboru przez autora satyry osoby mówiącej. Mieleszko to oczywiście litewski senator, ale czyż można nie zauważyć komizmu tej postaci? Elementy humorystyczne, o których jedynie towarzyszącej obecności pisze Struminsky, nie są przejawem jakiegoś nadzwyczajnego skomplikowania i niemal współczesnej kapryśności tekstu. One rozsadzają spójność przedstawionej przez badacza interpretacji przesłania ideowego tekstu, odbierając mówcy to, co najważniejsze: wiarygodność i sprzężony $\mathrm{z}$ nią autorytet.

Zaprezentowane przez Struminsky'ego ustalenia dotyczące cech językowych mowy sprawiają wrażenie niepodważalnych ${ }^{56}$. Zaskakujący wydaje się jednak fakt, że badacz, który zestawił 11 przekazów mowy, stwierdzając, że były napisane po polsku lub przepisane cyrylicą z tekstów oryginalnie utrwalonych po polsku, i który w końcu musiał dokonać transkrypcji mowy Pseudo-Mieleszki na język ukraiński, nie uwzględnił tego

${ }^{56}$ Jednak przy konsekwentnej analizie cech językowych ukraińskich i białoruskich zaskakująca wydaje się całkowita nieobecność polskich elementów językowych. A przecież już same zwroty grzecznościowe, nazwy geograficzne (Wołyń, Podlasie, Kijów), słowa zapożyczone, np. „fortugal”, „falandysz”, „szabinkować" (co sam autor opracowania odnotowuje w przypisach) czy np. „małzonka”, „na tandecie" każą chociaż postawić problem obecności języka polskiego. 
faktu i jego konsekwencji dla postawienia pytania o recepcję tekstu. Jeśliby przyjąć hipotezy badacza na temat autorstwa i wymowy satyry, to kto i po co mialby ten tekst przepisywać po polsku? Oczywiście możliwe wyjaśnienia są różne, ale najprostsze $z$ nich znowu uderza w odczytanie przedstawione przez Struminsky'ego. Może kopiujący tekst polskojęzyczni czytelnicy byli nim zainteresowani, bo inaczej odczytywali przesłanie satyry. Można by się upierać, że byłoby to tylko odczytanie przez nich narzucone, ale nawet i wtedy pozostawałoby pytanie o miarę literackiego sukcesu. Sukcesu satyry, która, jak świadczą przekazy, świetnie funkcjonowała z „błędnym” odczytaniem, podczas gdy zupełnie nie pozostały ślady odczytania zgodnego z przypisywaną jej przez Struminsky'ego autorską intencją, związanego dość naturalnie z cyrylickim zapisem.

W konsekwencji badacz sam popada w sprzeczność. Daje bowiem takie oto wyjaśnienie:

Many copies had to be made in the Polish script because officers and soldiers in the Smolensk border area admittedly often did not know Cyrillic ${ }^{57}$.

Najwyraźniej więc jednak to dla polskich czytelników tekst miał być przeznaczony, tylko przyjąwszy jego „poważną” wymowę, proponowaną przez badacza, trudno pojąć, co miałoby ich do jego czytania zachęcić.

Pozostaje jeszcze do rozważenia sprawa podstawowa: ustalenie przez Struminsky'ego przypuszczalnej daty powstania tekstu.

As for the possible time when our man from western Polissia wrote the M[elesko] $S[$ peech $]$ at Smolensk, our most obvious time limit is from the beginning of 1615 when Meleško became a castellan of Smolensk to July 20, 1663, when a White-Ruthenian Cyrillic copy (from a Polish script text) was recopied in the eastern corner of the Berestja palatinate ${ }^{58}$.

Terminus ad quem zostaje dalej przesunięty na podstawie faktów historycznych odzwierciedlonych w tekście (Kijów jako część Rzeczypospolitej — rok 1648; panowanie Zygmunta III - rok 1632; wojna ze Szwecją — rok 1622). Jednak kolejnemu argumentowi trzeba całkowicie odmówić mocy dowodowej. Autor bezpodstawnie wiąże pochodzenie kolejnych przekazów z czyjejś biblioteki z dziejami jego przodków i ich udziałem w wojnie polsko-moskiewskiej. Tak na przyklad osiemnastowieczny kopiariusz z Biblioteki Zakładu Narodowego im. Ossolińskich przez samą lokalizację ma być związany z przodkami założyciela biblioteki, Józefa Maksymilana Ossolińskiego, a konkretnie z osobą Jerzego Ossolińskiego, który brał udział w kampanii moskiewskiej 1617-1618. Nie trzeba dowodzić, jak dalece bardziej skomplikowana jest spra-

${ }^{57}$ Pseudo-Meleško..., op. cit., s. 112.

${ }^{58}$ Zob. ibidem, s. 111. 
wa proweniencji poszczególnych rękopisów i jak nieuprawniona jest sformułowana na takich podstawach konkluzja, ograniczająca czas powstania satyry do lat kampanii $1615-1618^{59}$.

Nie ulega wątpliwości, że satyryczne wotum jest związane z osobą Jana Eliasza Mieleszki. który był postacią literaturze satyrycznej nieobcą. O jego popularności świadczy odnaleziony przez Łastowskiego satyryczny list z 1655 r. do Filipa Obuchowicza, w którym cytowany jest fragment jego mowy, broniący prostych ludzi i krytykujący wyszukane wielomówstwo wraz z komentarzem, że to sam senator został oceniony jako $\operatorname{prostak}^{60}$. Mieleszko pojawił się też w rokoszowej satyrze na senat, w której przypisano mu określenie: „Stultorum exsultatio ignominia est” [Radość głupców jest zniewaga]. Niewykluczone więc, że pamfletowe ostrze skierowane było wlaśnie przeciw niemu. Był on senatorem, który szybko awansował po porzuceniu prawosławia na rzecz unii, mógł budzić niechęć zarówno wiernych dawnemu wyznaniu, jak i tych polskich możnych, którzy jak Janusz Radziwiłł głośno wyrażali lekceważenie wobec senatorów o niezbyt wysokim pochodzeniu, takich jak Kossobudzki i Mieleszko ${ }^{61}$. Zarówno Urszula Meierin, jak i Jan Eliasz Mieleszko pojawili się w satyrze rokoszowej, być może więc również z okresem tego szczególnego ożywienia literatury polityczno-okolicznościowej wiąże się rzekoma mowa kasztelana smoleńskiego.

Mimo imiennego nakierowania, satyryczne treści wotum Pseudo-Mieleszki są bardzo ogólnej natury, przynależą przede wszystkim do dawnej i szeroko rozpowszechnionej tradycji satyry obyczajowej i równie popularnej krytyki różnych nacji (np. Różność nacyj z ich wtasnościami Jana z Kijan), gdyż poważne, społeczne troski unieważnia karykaturalny wizerunek mówcy. Wszystkie sprawdzone środki satyry zyskują na ostrości wyrazu przez skojarzenie ich z oficjalną konwencją senatorskiego wotum. Jeśli by jednak spojrzeć szerzej na satyrę polityczną XVII wieku, to okaże się, że na podobnej zasadzie działający kontrast pomiędzy tym, co wysokie i co niskie, pojawiał się szczególnie wyraźnie w parodiach modlitw czy tekstów biblijnych. W obydwu wypadkach gwarancją skuteczności wyostrzenia satyrycznego ostrza było rozpoznanie konwencji i odczucie przez odbiorcę silnego napięcia między oficjalnym wzorcem i jego komiczną realizacją. Zakładana znajomość tej konwencji również zbliża parodię sejmowego wotum do kręgu polskich czytelników.

59 W sferze całkowitej dowolności można umieścić np. taką hipotezę autora, mającą wyjaśnić fakt, że tytuł mowy konsekwentnie był zapisywany już nie tylko polskim alfabetem, ale po polsku: „For security reasons perhaps, the author of the $M S$ or one of his friends gave it a Polish title indicating that this uas an old dokument of 1589 (a purely fantasied dated)" (ibidem, s. 112) Istotnie, może całkowicie fantastyczna data, ale i równie fantastyczne pierwsze przypuszczenie, jakież to bowiem treści mogły być tak dla autora groźne, pozostaje tajemnicą.

${ }^{60}$ Zob. Pseudo-Meleško..., op. cit., s. 14.

${ }^{61}$ Księcia Krzysztofa Radziwitła hetmana polnego Wielkiego Księstwa Litewskiego sprauy wojenne i polityczne (1621-1632), Paryz 1859, s. 699. 
Zebrane tu, dotychczas odnalezione ${ }^{62}$, dokumenty istnienia komicznej odmiany także w zakresie świeckiego oratorstwa dobrze wpisują się we wskazane przez Kazimierę Żukowską odmiany humorystycznych kazań. Do parodii typu pamfletowego lub krytycznego, posiadających łatwo dający się określić adres satyryczny, można włączyć zarówno mowy weselne identyfikujące swych bohaterów, jak i wotum krytykujące Mieleszkę. Pozostałe oracje weselne i komiczną mowę pogrzebową potraktować natomiast jako realizacje parodii komicznej lub ludycznej, czyli takiej, „która nie traktuje «poważnie przedmiotu komizmu, a jej celem ostatecznym jest wywołanie wesołości samej dla siebie»" ${ }^{3}$. Zdarzają się w nich wycieczki satyryczne, ale są one dość ogólnej i tradycyjnej natury. Niezależnie od tego, czy oracje komiczne, odwołujące się do różnych odmian konwencjonalnych mów weselnych, pogrzebowych i politycznych, wkraczały w obszar paszkwilu bądź anegdoty przez związanie z konkretnymi okolicznościami historycznymi czy też w całości przypisane były kulturze wesołej zabawy, są pośrednio dowodem głębokiego wrośnięcia tychże konwencji w świadomość odbiorczą, dowodem ich popularności i łatwej rozpoznawalności. $Z$ jednej strony poszerzają paletę komicznych parodii, z drugiej — raz jeszcze pokazują, że środki uzyskiwania komizmu mają w nich różne, ale już znane zastosowania. W konsekwencji również mowy komiczne dostarczają jeszcze jednego dowodu, że oratorstwo współtworzy staropolską dziedzinę literackości.

${ }^{62}$ Trzeba do nich dołączyć prawdopodobnie jeszcze Mowę $w$ Trybunale Koronnym Księdza Hadziewicza na jedno oko niewidomego, ekskuzując się, że dziewczyne za chtopca chowat, za co do wieży byt skazany, lecz tymi eliberowat się stoury, rkps BN BOZ 1282, s. 5.

${ }^{63}$ K. Żukowska, Próba spojrzenia..., op. cit., s. 207-208 i 210-211. 